American Journal of Economics and Business Administration 3 (3): 560-568, 2011

ISSN 1945-5488

(C) 2011 Science Publications

\title{
Why the Dogs of the Dow Bark Loudly in China
}

\author{
Carol Wang, James E. Larsen, Fall M. Ainina, \\ Marlena L. Akhbari and Nicolas Gressis \\ Department of Finance and Financial Services, Raj Soin College of Business, \\ Wright State University, 3640 Colonel Glenn Highway, Dayton, OH 45435, USA
}

\begin{abstract}
Problem statement: The Dogs of the Dow (Dow Dogs) strategy, which has gained widespread popularity in the U.S., is found to be considerably successful in China's stock markets. This trading strategy contradicts the well-established efficient market hypothesis. Approach: This study examines the cross-sectional variations in the magnitude of the predictive power of the Dow Dogs strategy using Chinese stocks for 1994-2009. Results: Our results suggest that (1) Significant Dow Dogs effect apply to Class A shares, but not Class B shares; (2) Stocks priced between $\$ 1$ and $\$ 5$ demonstrate the strongest Dogs effect among all stock price ranges; (3) Changes in share price range has the most powerful impact on risk adjusted return, followed by changes in the $A B$ share class, rebalancing frequency and number of Dogs in the portfolio. Conclusion: Our results suggest that the superior predictive power of the Dow Dogs strategy is mainly driven by behavioral factors. Our overall findings support the behavioral hypothesis in which market inefficiency stems from investors irrationality and herding behaviors. This study provides practical implications to both government regulators and finance practitioners. JEL Classification: G14, G15.
\end{abstract}

Key words: Dogs of the Dow, China stock market, market efficiency, Dow Jones Industrial Average (DJIA), capital markets, foreign investors, herding behaviors, market economy, Shenzhen Stock Exchange (SZSE), State-Owned Enterprises (SOEs)

\section{INTRODUCTION}

The Dogs of the Dow strategy was first brought to public attention in 1988 by a Wall Street Journal article (Dorfman, 1988) which documents that during the period 1972-1987, the performance of the ten highest yielding Dow Jones Industrial Average (DJIA) stocks beat the DJIA by an average annual return of $7.6 \%$. Ever since, this trading technique has gained tremendous popularity in the investment community. This trading strategy seems to contradict the well-established efficient market hypothesis and it has triggered a large body of academic research in both the U.S. and internationally to investigate the causes of this anomaly. Various explanations have been proposed and some studies have found inconsistent performance of this trading strategy. To date, no consensus has been reached on the true nature of the Dow Dogs. Motivated by this on-going debate, we examine the cross-sectional variations in the predictive effects of the Dow Dogs strategy in China and shed light on this controversial subject.
Over the past two decades, China has experienced dynamic economic growth and emerged as the second largest national economy. Its capital markets are expanding rapidly to accommodate its transition from a centralized control system to a market economy and both domestic and foreign investors pursuing global diversification opportunities have been attracted to these markets. China's institutional structure and the early stage of its capital market development result in a trading environment with a few features that may promote speculative activities, but it also provides a unique setting for us to investigate the sources of the market anomaly associated with the Dow Dogs strategy.

Our results suggest that the superior predictive power of the Dow Dogs strategy is mainly driven by behavioral factors. Specifically, we find that the significant Dow Dogs effect prevails in class A shares but not in class B shares. In addition, the abnormal returns are more pronounced for stocks priced between $\$ 1$ and $\$ 5$, than for stocks in other price ranges. Previous literature has established the connection between share turnover ratio and irrational market sentiment. We find that class A shares and stocks

Corresponding Author: Carol Wang, Department of Finance and Financial Services, Raj Soin College of Business,

Wright State University, Colonel Glenn Highway, Dayton, OH 45435, USA

Tel: 001-(937)241-3185 Fax: (937)775-3545 
between $\$ 1$ and \$5 have significantly higher turnover ratio than stocks in other categories, suggesting that the capital flow caused by human psychological factors play an important role in the market anomaly induced by the Dow Dogs strategy. Our overall findings support the behavioral hypothesis in which market inefficiency stems from investors irrationality and herding behaviors. This study provides practical implications to both government regulators and finance practitioners.

China's stock markets: Currently, mainland China has two stock exchanges. They are the Shanghai Stock Exchange (SHSE), established in 1990 and the Shenzhen Stock Exchange (SZSE), established in 1991. Both markets have expanded rapidly and are ranked the third and fifth largest stock exchanges in the world based on total value of shares traded by the end of 2009 World Federation of Exchanges.

Chinese stock markets have several distinguishing characteristics that stem from its special institutional structures that may foster a higher level of exuberant investor behavior. First, Chinese markets are segmented between domestic and foreign investors through class A and B shares. Most listed companies issue A shares. A small proportion of listed companies issue both $\mathrm{A}$ and $\mathrm{B}$ shares or issue B shares only. Class A shares are quoted in Chinese Yuan and are restricted to domestic investors and selected foreign institutional investors. Class B shares are quoted in foreign currencies and were available only to foreign investors before March 2001. Since March 2001, Chinese investors can also trade B shares with legal foreign currency accounts. However, Chinese investors have limited access to foreign currency. The A share market is known to be dominated by individual investors who normally have less expertise and resources than institutional investors and, therefore, may be more subject to speculative forces.

Second, China's legal system is still developing. The quality of Chinese security laws in terms of disclosure standards and enforcement are relatively weak. The level of information transparency between public investors and firm managers is lower than in common law countries such as the U.S. (La Porta et al., 1998). Information asymmetry is known to create incentives for opportunistic behavior among investors. Currently, companies that issue both A and B shares are required to prepare two version of financial statements. One is based on China's domestic Generally Accepted Accounting Principles (GAAP) for the A share holders, the other is based on International Accounting Standards (IAS) for the B share holders. The level of disclosure is stricter for the B class shares (Bao and Chow, 1999).

In addition, still in their burgeoning stage, China's security markets offer limited investment and hedging alternatives and a limited number of stocks to meet the investment needs of a growing investor base in a booming economy. For example, short sales are banned in China and option markets are non-existent. These limits present considerable barriers to arbitrage mispricing in the equity market and create greater potential of market bubbles and anomalies over time.

Finally, China's State-Owned Enterprises (SOEs) are still in the middle of the privatization process, a large portion of the issued shares of the listed companies are state shares, legal person shares and employee shares, none of which are available for public investors (Sun and Tong, 2003). Non-tradable shares as a fraction of total shares has been declining since 2005 after China put forth a series of programs to accelerate privatization. However, in 2008 the present central government embarked on a reversing process of market economy reform and tightened the control of state ownership of the major enterprises in China. The average non-tradable ratio during our sample period is $53.8 \%$. That the number of available shares does not match the increasing investment needs of Chinese households further exacerbates the market exuberance problem. These special attributes of current Chinese markets, however, afford us the opportunity to compare the predictive power of the Dow Dogs strategy across behavioral variables that would be difficult to accomplish in more developed markets.

Literature review: The article that introduced the Dogs of the Dow strategy appeared in the Wall Street Journal in 1988 (Dorfman, 1988). It documented the abnormal returns earned over the market by applying the Dow Dogs strategy for the period 1972-1987. O'Higgins and Downes (1991) and Knowles and Petty (1992) confirmed the effectiveness of the Dow Dogs strategy and highly promoted this simple trading concept to the public. Ever since, this trading technique has received a wealth of attention from both financial practitioners and academia.

The Dogs of the Dow is one of several investment strategies that challenge the efficient market hypothesis (Fama, 1970) (Researchers have provided evidence of other market anomalies, including the P/E ratio (Basu, 1977; Campbell and Shiller, 1988b; Fama and French, 1988), dividend yield (Fama and French, 1988), bookto-market ratio (Kothari and Shanken, 1997), aggregate insider trading (Nejat, 1988), dividend-price ratio (Campbell and Shiller, 1988a), and equity share (Baker and Wurgler (2000), to name a few). These market anomalies have inspired two popular explanations that provide different perspectives on the subject. One is based on implications of the traditional efficient market hypothesis. The other is based on the recently emerged 
behavioral hypothesis that allows for irrational behavior on the part of investors.

Proponents of the efficient market hypothesis assume that investors are rational and any over-reaction or under-reaction of investors tends to offset or cancel out any mispricing. Hence, prices normally reflect true asset value (Fama, 1998). According to Black (1993), some of the anomalous evidence is purely a result of data mining or statistical artifacts. Davis et al. (2000) reason that due to the limits of currently developed theories and models, some unobserved risks of the assets cannot be fully captured by the Capital Asset Pricing Model and, therefore, the market anomalies are a result of investors' biased perception of true asset value. Fama and French (1993; 1995; 1996) propose multi-factor models that appear to explain the average returns on a full scale.

The behavioral camp, on the other hand, relaxes the assumption of investor rationality. Albert Einstein once said "Only two things are infinite, the Universe and Human Stupidity and I'm not sure about the former." The behaviorists believe that investors are subject to various cognitive errors and can make illogical and irrational investment decisions. According to Barber and Odean (1999), people's deviations from rationality are often systematic. Systematic over-reaction to information is common among investors. When the over-reaction is eventually corrected, over-adjusted stock returns converge or reverse. Hogarth and Reder (1986); Einhorn and Hogarth (1986); Kleidon (1986); De Bondt et al. (1987) and Lakonishok et al. (1994) are among the group that support the behavioral hypothesis.

The effectiveness and logic of the Dow Dogs has also been debated among academics for many years. The initial rationale offered for the superior performance of Dow Dog portfolios was that the high dividend yield best represents the company's future perspective relative to its stock price and over time the price will revert to a normal level. O'Higgins and Downes (1991) claim that the Dow Dogs strategy is based on simple logic and may produce returns in any rational market. However, a natural question is raised as to why public investors cannot recognize the economic value of the predictive effect of this strategy and eventually arbitrage away the opportunity.

To date, the puzzle of the Dogs of the Dow anomaly remains unsolved. Domian et al. (1998) compare the Dow Dogs effect during, before and after the 1987 market crash and argue that the Dogs effect is a loser-winner effect during the pre-crash period. Hirschey (2000) carefully replicates the Dow Dogs strategy and argues that the previously documented exceptional return of the Dogs is caused by data errors and data mining and, therefore, that the Dow Dogs effect still conforms to the traditional asset pricing model. However, Prather and Webb (2001) reexamine the Dow Dogs approach and refute Hirschey (2000) data mining explanation. The Chinese stock markets examined in the present research effort offer an interesting new venue in which to continue the analysis of the Dow Dogs.

Data: We obtain monthly dividend yield data from Morningstar Direct and daily market returns, with cash dividends reinvested, from the Chinese Securities Market and Accounting Research databases (CSMAR). Observations with daily average trading volume less than 50,000 shares are eliminated to ensure liquidity. We compute the monthly returns from the daily returns and convert all shares into US dollars based on historical currency exchange rates. In addition, observations prior to 1994 are excluded because of infrequent trading during this time period. After merging the two datasets, our sample contains 1,611 stocks covering 105,429 firmmonth observations. Out of the 1,611 stocks, 1,509 are in class A and 102 are in class B.

In formulating portfolios, an approach similar to that employed by Ainina et al. (2010) is followed to examine the price level impact on the performance of the trading strategy. In separate iterations, our portfolios are restricted to shares with prices: (1) lower than $\$ 1$; (2) greater than or equal to $\$ 1$ and lower than $\$ 5$; (3) greater than or equal to $\$ 5$ and lower than $\$ 10$; (4) greater than or equal to $\$ 10$; (5) greater or equal to $\$ 1$; and (6) greater than or equal to $\$ 5$.

Table $1 \mathrm{~A}$ and $\mathrm{B}$ report the average level of monthly dividend yields and average turnover ratio, respectively, across different stock price ranges for each year in the study. The Turnover Ratio is computed by dividing the average total market value of traded shares by the average total market value of tradable shares of our sample for each month.

Previous studies have established a positive relationship between share turnover and the investor speculation (Merton, 1987; Cochrane, 2002; Mei et al., 2009). Merton (1987) argues that the size of the investor base is associated with market value of the stocks. Similarly, Cochrane (2002) finds that high share turnover ratio explained high prices during the technical bubble in the late 1990s. Mei et al. (2009) provide empirical evidence on how China's a share premium is driven by heavy turnover ratio. Table 1 shows that both variables fluctuate with market movements. Stocks priced between $\$ 1$ and $\$ 5$ have the highest average turnover ratio and stocks below $\$ 1$ have the lowest average turnover ratio. This pattern suggests that for a fixed amount of tradable shares, price between $\$ 1$ and $\$ 5$ is the most popular stock price range while stocks priced below $\$ 1$ receive the least attention among investors. 
Am. J. of Economics and Business Administration 3 (3): 560-568, 2011

Table 1: Descriptive statistics across price ranges over sample years (A) Average monthly dividend yield across price ranges over sample years

\begin{tabular}{lcccc}
\hline Year & $\begin{array}{l}\text { Price } \\
<\$ 1(\%)\end{array}$ & $\begin{array}{l}\$ 1 \leq \text { Price } \\
<\$ 5(\%)\end{array}$ & $\begin{array}{c}\$ 5 \leq \text { Price } \\
<\$ 10(\%)\end{array}$ & $\begin{array}{c}\text { Price } \geq \\
\$ 10(\%)\end{array}$ \\
\hline 1994 & 3.11 & 2.06 & 2.52 & 2.11 \\
1995 & 4.04 & 2.91 & 2.64 & 1.97 \\
1996 & 3.85 & 2.22 & 2.52 & 1.70 \\
1997 & 2.76 & 1.54 & 1.46 & 1.06 \\
1998 & 4.90 & 1.71 & 1.48 & 1.13 \\
1999 & 4.86 & 1.68 & 1.51 & 1.40 \\
2000 & 4.05 & 1.29 & 1.13 & 1.00 \\
2001 & 2.15 & 1.17 & 0.87 & 0.99 \\
2002 & 1.77 & 1.24 & 1.02 & 0.99 \\
2003 & 1.67 & 1.43 & 1.16 & 1.21 \\
2004 & 2.11 & 1.71 & 1.31 & 1.64 \\
2005 & 3.00 & 2.51 & 1.74 & 2.45 \\
2006 & 2.88 & 2.32 & 1.42 & 1.59 \\
2007 & 1.63 & 1.16 & 0.79 & 0.68 \\
2008 & 2.75 & 1.78 & 1.24 & 1.06 \\
2009 & 2.57 & 1.51 & 1.13 & 1.19 \\
Average & 3.01 & 1.76 & 1.50 & 1.38 \\
\hline
\end{tabular}

Table 1B: Average turnover ratio across price ranges over sample years

\begin{tabular}{lllll}
\hline Year & $\begin{array}{l}\text { Price } \\
<1(\%)\end{array}$ & $\begin{array}{l}\$ 1 \leq \text { Price } \\
<\$ 5(\%)\end{array}$ & $\begin{array}{l}\$ 5 \leq \text { Price } \\
<\$ 10(\%)\end{array}$ & $\begin{array}{l}\text { Price } \geq \\
\$ 10(\%)\end{array}$ \\
\hline 1994 & 37.40 & 50.40 & 32.50 & 42.80 \\
1995 & 18.20 & 20.10 & 21.40 & 16.50 \\
1996 & 34.00 & 57.80 & 31.30 & 29.90 \\
1997 & 24.90 & 33.90 & 28.10 & 29.40 \\
1998 & 16.10 & 20.70 & 16.70 & 21.10 \\
1999 & 19.00 & 18.80 & 16.20 & 20.40 \\
2000 & 11.20 & 24.20 & 20.20 & 20.70 \\
2001 & 14.70 & 11.10 & 9.20 & 11.60 \\
2002 & 8.20 & 9.30 & 8.10 & 8.70 \\
2003 & 9.00 & 10.00 & 7.90 & 9.00 \\
2004 & 10.30 & 15.30 & 12.40 & 11.50 \\
2005 & 14.00 & 16.50 & 10.80 & 14.10 \\
2006 & 24.20 & 31.90 & 26.20 & 24.10 \\
2007 & 37.70 & 51.30 & 43.30 & 33.20 \\
2008 & 17.40 & 27.50 & 25.40 & 19.60 \\
2009 & 20.40 & 46.20 & 42.20 & 31.00 \\
Average & 19.80 & 27.80 & 22.00 & 21.50 \\
\hline
\end{tabular}

Table 2: Descriptive statistics between class A and Class B shares over sample years (A) average monthly dividend yields between class A shares and Class B shares over sample Years

\begin{tabular}{lll}
\hline Year & $\mathrm{A}(\%)$ & $\mathrm{B}(\%)$ \\
\hline 1994 & 2.34 & 3.69 \\
1995 & 3.08 & 5.95 \\
1996 & 2.48 & 5.51 \\
1997 & 1.42 & 3.59 \\
1998 & 1.52 & 7.19 \\
1999 & 1.62 & 6.73 \\
2000 & 1.23 & 4.61 \\
2001 & 1.09 & 2.01 \\
2002 & 1.19 & 2.16 \\
2003 & 1.38 & 2.29 \\
2004 & 1.74 & 2.43 \\
2005 & 2.61 & 4.05 \\
2006 & 2.28 & 3.35 \\
2007 & 0.94 & 1.52 \\
2008 & 1.52 & 3.26 \\
2009 & 1.24 & 4.27 \\
Average & 1.73 & 3.91 \\
\hline
\end{tabular}

Table 2B:Average share turnover ratio between class $\mathrm{A}$ shares and class B shares over sample years

\begin{tabular}{lrr}
\hline Year & $\mathrm{A}(\%)$ & $\mathrm{B}(\%)$ \\
\hline 1994 & 44.50 & 33.20 \\
1995 & 18.60 & 20.10 \\
1996 & 49.10 & 22.90 \\
1997 & 33.10 & 21.80 \\
1998 & 20.30 & 15.20 \\
1999 & 18.40 & 21.90 \\
2000 & 23.70 & 6.00 \\
2001 & 10.20 & 19.90 \\
2002 & 9.60 & 4.20 \\
2003 & 10.10 & 4.20 \\
2004 & 14.40 & 3.80 \\
2005 & 16.00 & 3.10 \\
2006 & 30.40 & 7.50 \\
2007 & 48.50 & 15.40 \\
2008 & 26.60 & 3.80 \\
2009 & 43.90 & 8.30 \\
Average & 26.10 & 13.20 \\
\hline
\end{tabular}

This evidence is also consistent with Brown and Mitchell (2008) finding on price clustering for A shares caused by a Chinese cultural effect. In Chinese culture, the number " 8 " is considered a lucky number and number " 4 " is considered unlucky. Investors may chase stocks with prices around 8 RMB Yuan, which is in the range of $\$ 1$ and $\$ 5$ after the currency conversion and avoid stocks priced around 4 RMB Yuan, which is below $\$ 1$.

Table $2 \mathrm{~A}$ and $\mathrm{B}$ compare the average dividend yield and average turnover ratio, respectively, between class A and class B shares over time. It shows B shares have significantly higher dividend yields than A shares. This large gap can be explained by the well documented price premium of A shares over their B counterparts (Bailey, 1994). It also is consistent with the dividend signaling theory that the information asymmetry between China's domestic market and foreign investors may force the company to pay high and consistent dividends to attract potential demand for $\mathrm{B}$ share stocks. The average turnover ratio of A shares exceeds that of B shares for most of our study period.

\section{MATERIAL AND METHODS}

We construct total 1,512 portfolios based on the Dogs of the Dow method. We first split the sample into six different price ranges and $\mathrm{AB}$ classes. Next we form the equally weighted portfolios by varying the holding periods before rebalancing and the number of companies included in the portfolios. Specifically, we select the top $\mathrm{N}$ stocks with the highest dividend yields during the previous three months starting from April 1994, where, in separate iterations, $\mathrm{N}=1,2,3,4,5,6$, $7,8,9,10,15,20,25,30,35,40,45$ and 50 and form equally weighted portfolios. Then, each portfolio is held for a certain number of months (M), where, in separate iterations, $\mathrm{M}=1,2,3,4,5,6$ and 12 
months. The portfolio is then reformulated every $M$ months using the above described selection criteria through the end of 2009 for each price category and each share class. This procedure results in the formulation of 1,512 portfolios ( 6 different price ranges multiplied by 2 share classes, 18 different portfolio sizes and 7 different holding periods). For each portfolio, we compute: (1) the Terminal Value (TV) of $\$ 1$ as an initial investment, (2) the Information Ratio and (3) the Batting Ratio.

To compute Information Ratio, the daily total value weighted aggregate market returns with cash dividends reinvested is used as the market benchmark. We convert the daily data into monthly returns from 1994 through 2009. In order to make a consistent comparison, in calculating both the Information and Batting Ratios, the holding period before rebalancing the market benchmark is set identical to the pertinent Dogs portfolio.

To compute the Information Ratio, we use the mean difference between portfolio returns of the subject portfolio and the benchmark returns as the numerator. The denominator is the portfolio's holding period tracking error, which is the standard deviation of the portfolio's holding period excess returns over the benchmark returns. Specifically, the formula for Information Ratio is as follows:

$$
\begin{aligned}
\text { Information Ratio } & =\frac{\text { Excess Return }}{\text { Tracking Error }} \\
& =\frac{\sum_{\mathrm{t}=1}^{\mathrm{T}}\left(\mathrm{R}_{\mathrm{t}}-\mathrm{R}_{\mathrm{bm}, \mathrm{t}}\right) / \mathrm{T}}{\sqrt{\frac{1}{\mathrm{~T}-1} \sum_{\mathrm{t}=1}^{\mathrm{T}}\left(\mathrm{e}_{\mathrm{t}}-\overline{\mathrm{e}}\right)^{2}}}
\end{aligned}
$$

Where:

$$
\begin{aligned}
& \text { Rt }=\text { Return of portfolio for time period } \mathrm{t} \\
& \mathrm{R}_{\mathrm{bm}, \mathrm{t}}=\text { Return of benchmark for time period } \mathrm{t} \\
& \mathrm{T}=\text { Number of time periods } \\
& \mathrm{e}_{\mathrm{t}} \quad=\text { Excess returns at time } \mathrm{t} \\
& \overline{\mathrm{e}} \quad=\text { Mean excess return }
\end{aligned}
$$

We calculate the batting ratio by dividing the number of months in which the performance of the subject portfolio beat or matched the market return by the total number of months in the study period. The formula is presented as follows.

Let I be the indicator function such that:

$$
\mathrm{I}(\text { True })=1
$$$$
\mathrm{I}(\text { False })=0
$$

$$
\text { Batting Ratio }=\sum_{\mathrm{t}=1}^{\mathrm{T}} \mathrm{I}\left(\mathrm{R}_{\mathrm{t}} \geq \mathrm{R}_{\mathrm{bm}, \mathrm{t}}\right) / \mathrm{T} \times 100
$$

Where:

$\mathrm{Rt}=$ Return of the subject portfolio for time period $\mathrm{t}$

$\mathrm{R}_{\mathrm{bm}, \mathrm{t}}=$ Return of the bench mark for time period $\mathrm{t}$

$\mathrm{T}=$ Number of time periods in the study

\section{RESULTS AND DISCUSSION}

Analysis of the cross-sectional performance: In the rest of this section, we analyze and compare the average Terminal Value of $\$ 1$ invested, the Information Ratio and the Batting Ratio across the various portfolio classifications. Table 3 compares the ratios among different stock price ranges. Table 3A shows that portfolios priced between $\$ 1$ and $\$ 5$ perform the best, with an average Terminal Value of $\$ 10.95$ compared to $\$ 5.85$ for the market benchmark. However, stocks below $\$ 1$ and between $\$ 5$ and $\$ 10$ fail to beat the market index. They underperform the market benchmark return, have Batting Ratios lower than 50\% and Information Ratios below zero.

The above pattern is consistent with the share turnover ratio ranking over different price ranges. The share turnover is the highest for stocks priced between $\$ 1$ and $\$ 5$ and greater than $\$ 10$ and lowest for stocks priced below $\$ 1$. From this, we conclude that investors' preference for shares trading within their favorite trading range constitutes an important reason for the performance of the Dow Dogs portfolios. This evidence confirms the hypothesis raised by Merton (1987) that investors' recognition drives up the size of investor base and may in turn boost asset values.

Table 3: Average terminal value of $\$ 1$ invested, information ratio and batting ratio over different numbers of included stocks across price ranges (A) average terminal values of $\$ 1$ over different numbers of stocks across price ranges

\begin{tabular}{lccccc}
\hline Top_N & $\begin{array}{l}\text { Price } \\
<\$ 1\end{array}$ & $\begin{array}{l}\$ 1 \leq \\
\text { Price }<\$ 5\end{array}$ & $\begin{array}{l}\$ 5 \leq \\
\text { Price }<\$ 10\end{array}$ & $\begin{array}{c}\text { Price } \\
\geq \$ 10\end{array}$ & $\begin{array}{l}\text { Market } \\
\text { Index }\end{array}$ \\
\hline 1 & 2.969 & 12.622 & 1.521 & 12.55 & 5.85 \\
2 & 3.087 & 12.303 & 2.259 & 9.633 & 5.85 \\
3 & 4.188 & 12.464 & 3.079 & 8.535 & 5.85 \\
4 & 4.374 & 12.684 & 2.114 & 8.823 & 5.85 \\
5 & 3.795 & 12.314 & 2.381 & 8.183 & 5.85 \\
6 & 3.495 & 11.718 & 2.530 & 8.529 & 5.85 \\
7 & 3.932 & 10.323 & 2.500 & 8.323 & 5.85 \\
8 & 5.688 & 9.804 & 2.502 & 7.139 & 5.85 \\
9 & 5.592 & 8.822 & 2.533 & 6.516 & 5.85 \\
10 & 5.340 & 10.071 & 2.446 & 6.559 & 5.85 \\
15 & 5.067 & 10.169 & 2.380 & 6.243 & 5.85 \\
20 & 4.478 & 9.674 & 2.324 & 6.061 & 5.85 \\
25 & 4.609 & 10.606 & 2.302 & 6.282 & 5.85 \\
30 & 4.529 & 10.546 & 2.278 & 6.258 & 5.85 \\
35 & 4.356 & 10.769 & 2.289 & 6.262 & 5.85 \\
40 & 4.229 & 10.817 & 2.250 & 6.078 & 5.85 \\
45 & 4.083 & 10.734 & 2.314 & 6.079 & 5.85 \\
50 & 4.087 & 10.634 & 2.258 & 5.961 & 5.85 \\
Average & 4.328 & 10.949 & 2.348 & 7.445 & 5.85 \\
\hline
\end{tabular}


Am. J. of Economics and Business Administration 3 (3): 560-568, 2011

Table 3B: Average information ratio over different numbers of stocks across price ranges

\begin{tabular}{lllll}
\hline 1 & 0.033 & 0.035 & -0.21 & 0.21 \\
\hline 2 & -0.026 & 0.070 & -0.193 & 0.184 \\
3 & -0.019 & 0.063 & -0.180 & 0.176 \\
4 & -0.003 & 0.064 & -0.246 & 0.183 \\
5 & -0.010 & 0.077 & -0.259 & 0.176 \\
6 & -0.025 & 0.069 & -0.257 & 0.178 \\
7 & -0.011 & 0.072 & -0.233 & 0.162 \\
8 & 0.037 & 0.071 & -0.256 & 0.140 \\
9 & 0.058 & 0.065 & -0.251 & 0.129 \\
10 & 0.049 & 0.085 & -0.253 & 0.130 \\
15 & 0.010 & 0.086 & -0.262 & 0.125 \\
20 & 0.000 & 0.087 & -0.285 & 0.120 \\
25 & 0.003 & 0.107 & -0.297 & 0.125 \\
30 & -0.019 & 0.116 & -0.296 & 0.123 \\
35 & -0.031 & 0.127 & -0.282 & 0.123 \\
40 & -0.042 & 0.127 & -0.283 & 0.117 \\
45 & -0.053 & 0.128 & -0.278 & 0.118 \\
50 & -0.053 & 0.125 & -0.280 & 0.114 \\
Average & -0.006 & 0.087 & -0.256 & 0.146 \\
\hline
\end{tabular}

Table (3C): Average batting ratio over different numbers of stocks across price ranges

\begin{tabular}{lllll}
\hline Top_N & $\begin{array}{l}\text { Price } \\
<1(\%)\end{array}$ & $\begin{array}{l}\$ 1<\text { Price } \\
\langle 5 \%\end{array}$ & $\begin{array}{l}\$ 5<\text { Price } \\
\langle \$ 10 \%\end{array}$ & $\begin{array}{l}\text { Price }> \\
\$ 10 \%\end{array}$ \\
\hline 1 & 48 & 51 & 44 & 52 \\
2 & 51 & 53 & 43 & 50 \\
3 & 50 & 51 & 43 & 54 \\
4 & 47 & 54 & 42 & 55 \\
5 & 48 & 55 & 41 & 56 \\
6 & 47 & 56 & 41 & 57 \\
7 & 49 & 55 & 43 & 55 \\
8 & 51 & 55 & 42 & 53 \\
9 & 52 & 55 & 43 & 53 \\
10 & 50 & 54 & 43 & 54 \\
15 & 51 & 55 & 42 & 53 \\
20 & 50 & 57 & 41 & 53 \\
25 & 50 & 59 & 41 & 53 \\
30 & 49 & 59 & 43 & 53 \\
35 & 48 & 59 & 43 & 53 \\
40 & 48 & 60 & 43 & 53 \\
45 & 47 & 60 & 43 & 53 \\
50 & 48 & 60 & 43 & 53 \\
Average & 49 & 56 & 42 & 54 \\
\hline
\end{tabular}

Table 4: Average terminal value of $\$ 1$ invested, information ratio and batting ratio over different holding periods (in Months) across price ranges

\begin{tabular}{lccllc}
\hline \multicolumn{6}{c}{ Price } \\
Holding_M & $\begin{array}{l}\$ 1 \leq \\
\text { Price }<\$ 5\end{array}$ & $\begin{array}{l}\$ 5 \leq \\
\text { Price }<\$ 10\end{array}$ & $\begin{array}{l}\text { Price } \geq \\
\$ 10\end{array}$ & $\begin{array}{l}\text { Market } \\
\text { Index }\end{array}$ \\
\hline 1 & 8.79 & 14.81 & 4.59 & 9.23 & 5.85 \\
2 & 4.86 & 14.08 & 2.16 & 9.21 & 5.85 \\
3 & 3.54 & 10.43 & 3.41 & 7.62 & 5.85 \\
4 & 2.8 & 16.41 & 1.9 & 7.5 & 5.85 \\
5 & 2.37 & 8.73 & 1.56 & 6.91 & 5.85 \\
6 & 2.53 & 8.06 & 1.39 & 4.93 & 5.85 \\
12 & 5.41 & 4.12 & 1.41 & 6.71 & 5.85 \\
Average & 4.33 & 10.95 & 2.35 & 7.45 & 5.85 \\
\hline
\end{tabular}

Table (4B): Average information ratio over different holding periods (in Months) across price ranges

\begin{tabular}{lllll}
\hline 1 & 0.06 & 0.07 & -0.06 & 0.09 \\
\hline 2 & 0.10 & 0.1 & -0.14 & 0.11 \\
3 & 0.02 & 0.09 & -0.17 & 0.14 \\
4 & 0.00 & 0.15 & -0.33 & 0.15 \\
5 & -0.03 & 0.18 & -0.26 & 0.20 \\
6 & -0.05 & 0.10 & -0.36 & 0.09 \\
12 & -0.14 & -0.09 & -0.47 & 0.25 \\
Average & -0.01 & 0.09 & -0.26 & 0.15
\end{tabular}

Table (4C): Average batting ratio over different holding periods (in Months) across price ranges

\begin{tabular}{lllll}
\hline 1 & $50.30 \%$ & $53.50 \%$ & $47.70 \%$ & $51.70 \%$ \\
\hline 2 & $50.10 \%$ & $54.70 \%$ & $41.90 \%$ & $56.80 \%$ \\
3 & $52.10 \%$ & $54.40 \%$ & $46.10 \%$ & $54.80 \%$ \\
4 & $48.00 \%$ & $59.80 \%$ & $36.10 \%$ & $48.10 \%$ \\
5 & $51.90 \%$ & $53.90 \%$ & $46.20 \%$ & $51.20 \%$ \\
6 & $49.10 \%$ & $58.30 \%$ & $33.70 \%$ & $52.40 \%$ \\
12 & $43.00 \%$ & $57.30 \%$ & $45.80 \%$ & $59.80 \%$ \\
Average & $49.20 \%$ & $56.00 \%$ & $42.50 \%$ & $53.50 \%$ \\
\hline
\end{tabular}

Table 5A: Average terminal value of $\$ 1$ invested, information ratio, and batting ratio across share classes

\begin{tabular}{|c|c|c|c|c|c|c|}
\hline \multirow[b]{2}{*}{ Top_N } & \multicolumn{2}{|c|}{$\begin{array}{l}\text { Terminal Value } \\
\text { of } \$ 1 \text { Invested }\end{array}$} & \multicolumn{2}{|c|}{$\begin{array}{l}\text { Information } \\
\text { Ratio }\end{array}$} & \multicolumn{2}{|c|}{$\begin{array}{l}\text { Batting } \\
\text { Ratio }\end{array}$} \\
\hline & A & $\mathrm{B}$ & A & B & $\mathrm{A}(\%)$ & $\mathrm{B}(\%)$ \\
\hline 1 & 11.8253 & 5.9 & 0.1 & -0.004 & 47.70 & 49.10 \\
\hline 2 & 16.6330 & 6.1 & 0.1 & -0.015 & 51.00 & 50.70 \\
\hline 3 & 17.4414 & 4.9 & 0.1 & -0.036 & 52.70 & 49.60 \\
\hline 4 & 16.1904 & 4.7 & 0.1 & -0.033 & 54.00 & 49.00 \\
\hline 5 & 15.8760 & 4.5 & 0.1 & -0.031 & 55.00 & 49.70 \\
\hline 6 & 14.6408 & 4.4 & 0.1 & -0.024 & 54.90 & 50.60 \\
\hline 7 & 12.8921 & 4.4 & 0.1 & -0.023 & 55.00 & 50.80 \\
\hline 8 & 12.4539 & 4.9 & 0.1 & -0.016 & 54.00 & 50.80 \\
\hline 9 & 11.7910 & 4.8 & 0.1 & -0.014 & 54.20 & 50.80 \\
\hline 10 & 12.6565 & 4.8 & 0.1 & -0.011 & 53.70 & 50.90 \\
\hline 15 & 12.2839 & 4.9 & 0.1 & -0.011 & 54.50 & 50.70 \\
\hline 20 & 11.7654 & 4.8 & 0.1 & -0.014 & 55.60 & 50.40 \\
\hline 25 & 11.4943 & 4.7 & 0.1 & -0.014 & 56.20 & 50.50 \\
\hline 30 & 10.9529 & 4.7 & 0.1 & -0.015 & 55.70 & 50.50 \\
\hline 35 & 10.9582 & 4.6 & 0.1 & -0.016 & 55.80 & 50.40 \\
\hline 40 & 11.0594 & 4.6 & 0.1 & -0.016 & 56.50 & 50.40 \\
\hline 45 & 10.9730 & 4.6 & 0.1 & -0.016 & 55.90 & 50.40 \\
\hline 50 & 10.7031 & 4.6 & 0.1 & -0.016 & 55.90 & 50.40 \\
\hline Average & 12.9217 & 4.8 & 0.1 & -0.018 & 54.40 & 50.30 \\
\hline
\end{tabular}

Table 5B: Average terminal value of $\$ 1$ invested, information ratio, and batting ratio over different holding periods (in Months) across share classes

\begin{tabular}{rllllc}
$\begin{array}{l}\text { Terminal } \\
\text { Value of \$1 Invested }\end{array}$ & \multicolumn{2}{l}{$\begin{array}{l}\text { Information } \\
\text { Ratio }\end{array}$} & Batting Ratio \\
\hline A & B & A & B & A $(\%)$ & B $(\%)$ \\
\hline 16.66388 & 6.1519 & 0.1125 & 0.0006 & 53.70 & 48.90 \\
15.96112 & 4.9421 & 0.1522 & -0.016 & 54.80 & 49.30 \\
13.75381 & 5.2658 & 0.1185 & 0.0074 & 54.80 & 51.60 \\
17.46453 & 5.0896 & 0.1372 & -0.0368 & 53.70 & 48.80 \\
10.00029 & 4.3504 & 0.1109 & 0.0553 & 55.90 & 49.40 \\
9.36925 & 4.1353 & 0.0676 & -0.0182 & 52.70 & 51.40 \\
7.23911 & 3.8863 & 0.0168 & -0.1188 & 54.80 & 52.90 \\
12.92171 & 4.8316 & 0.1023 & -0.0181 & 54.40 & 50.30
\end{tabular}

Table 3B and 3C demonstrate that only stocks trading between $\$ 1$ and $\$ 5$ grow in value as greater numbers of stocks are included in the subject portfolio.

The other price ranges show the opposite trend, suggesting that the diversification effect by holding more stocks applies selectively. Stocks priced greater than $\$ 10$ have higher information ratios than stocks between $\$ 1$ and $\$ 5$, indicative of the relatively low price volatility for higher priced shares. 
Table 4 reports the comparative performance over different holding periods across different price ranges. In Table 4A stocks of all price ranges show a slight downward overall trend as we extend the holding period before rebalancing up to twelve months. Stocks priced between $\$ 1$ and $\$ 5$ realize the highest average Terminal Value, $\$ 10.95$, equivalent to an annualized return of $17.3 \%$, followed by stocks priced greater than $\$ 10$. Again, stocks below $\$ 1$ and between $\$ 5$ and $\$ 10$ fail to beat the market index. In Table $4 \mathrm{~B}$ and $4 \mathrm{C}$, stocks priced between $\$ 1$ and $\$ 5$ and stocks greater than $\$ 10$ lead other price ranges in the Batting Ratio and Information Ratio. Table 5A reports the performance results based upon the number of stocks included in the subject portfolio and across share type. A shares outperformed B shares substantially based on all three measurements for all portfolios. Table (5B) compares the performance over different holding periods by share type. Significant abnormal returns are observed for shares, but not for B shares. The average Terminal Value for A shares is $\$ 12.92$, comparative to an annualized return of $18.6 \%$, exceeding the market index returns of $12.5 \%$, while B shares have an average Terminal Value of $\$ 4.83$, an equivalent annualized return of $11.06 \%$. A shares' average Batting Ratio and Information Ratio are $54.35 \%$ and 0.10 , while $\mathrm{B}$ share have an average Batting ratio of $50.3 \%$ and -0.018 . Note that as the number of stocks included in the portfolios increases, both the Terminal Value and the Information Ratio decrease for A shares, indicating that including more stocks does not help improve either the raw returns nor the risk-adjusted returns.

As a further robustness check, we apply the following stepwise regression model:

$$
\begin{aligned}
& \mathrm{R}_{\mathrm{i}}=\alpha+\beta_{1} \mathrm{X}_{1, \mathrm{i}}+\beta_{2} \mathrm{X}_{2, \mathrm{i}}+\beta_{3} \mathrm{D}_{1, \mathrm{i}}+\beta_{4} \mathrm{D}_{2, \mathrm{i}} \\
& +\beta_{5} \mathrm{D}_{3, \mathrm{i}}+\beta_{6} \mathrm{D}_{4, \mathrm{i}}+\beta_{7} \mathrm{D}_{5, \mathrm{i}}+\beta_{8} \mathrm{D}_{6, \mathrm{i}}+\varepsilon_{\mathrm{i}, \mathrm{t}}
\end{aligned}
$$

\section{Where:}

$\mathrm{R}_{\mathrm{i}}=$ The Terminal Value of portfolio I;

$\mathrm{X}_{1, \mathrm{i}}=$ The number of companies included in portfolio $\mathrm{I}$,

$\mathrm{X}_{2, \mathrm{i}}=$ The number of holding period (in months) before rebalancing for portfolio I,

$D_{1, \mathrm{i}}=$ Dummy variable that equals " 1 ' if shares in portfolio i are class A shares, or " 0 " if class B shares,

$\mathrm{D}_{2, \mathrm{i}}=$ A dummy variable that takes a value of "1" if portfolio i contains stocks priced greater than $\$ 1$, " 0 " otherwise,
$\mathrm{D}_{3, \mathrm{i}}=\mathrm{A}$ dummy variable that takes a value of "1" if portfolio i contains stocks priced between $\$ 1$ and $\$ 5$, "0" otherwise $\mathrm{D}_{4, \mathrm{i}}$ is a dummy variable that takes a value of " 1 " if portfolio i contains stocks priced between $\$ 5$ and $\$ 10$, " 0 " otherwise.

$\mathrm{D}_{5, \mathrm{i}}=\mathrm{A}$ dummy variable that takes a value of "1" if portfolio i contains stocks priced greater than $\$ 10$, “0" otherwise

$D_{6, i}=A$ dummy variable that takes a value of "1" if portfolio i contains stocks priced greater than $\$ 5$, "0" otherwise.

In Eq. 1, class B shares and stocks priced below $\$ 1$ are the hold-out categories. We also test Eq. 1 after replacing the Terminal Value with the Information Ratio. Table 6A of Table 6 reports the coefficient estimates of the regression when the dependent variable is the Terminal Value. The adjusted $\mathrm{R}^{2}$ is $46.43 \%$ and all coefficients are statistically significant at the $1 \%$ level. The intercept is 3.83 , representing the average Terminal Value for portfolios in class B shares and priced below $\$ 1$. The coefficients of $\beta_{1}$ for the number of included companies and $\beta_{2}$ for the holding month(s) before rebalancing are -0.054 and -0.55 respectively. They are both statistically significant and negatively related to the Terminal Value, but not economically significantly.

The coefficient of $\beta_{3}$ is 8.09. It suggests that on average Terminal Value for class A shares beat class B shares by $\$ 8.09$, or by $14.9 \%$ annual return. Stocks priced greater than $\$ 1$ earned an extra $\$ 13.49$ of Terminal Value, or $18.9 \%$ annual return above stocks priced below $\$ 1$. Stocks priced between $\$ 1$ and $\$ 5$ earned an extra $\$ 6.62$ or $13.4 \%$ annual return on average. The primary source of the superior performance of stocks priced greater than $\$ 1$ comes from stocks priced between $\$ 1$ and $\$ 5$. From Table 1 and 2 summary statistics, both A shares and stocks priced between $\$ 1$ and $\$ 5$ have significantly greater average turnover ratio than other categories, suggestive of a connection between abnormal return and turnover ratio. Table $6 \mathrm{~B}$ presents the regression results of Eq. 1 with the Information Ratio as the dependent variable. The adjusted $\mathrm{R}^{2}$ is $57.11 \%$ for this estimate.

Except for the intercept, all coefficient estimates are significant at $1 \%$ level. Stocks priced greater than $\$ 1$ lead the Information Ratio by 0.189 over stocks priced below $\$ 1$. The major contributor of the high information ratio is stocks priced greater than $\$ 10$. The Information Ratio for class A shares is 0.12 greater than class $\mathrm{B}$ shares on average. 
Table 6: Cross-sectional regressions of portfolio performance Table (6A) A: Ri = Terminal Value

\begin{tabular}{|c|c|c|}
\hline Independent Variable & Estimate & $\mathrm{P}$-value \\
\hline Intercept & $3.836 * * *$ & $<0.01$ \\
\hline Top_N & $-0.054 * * *$ & $<0.01$ \\
\hline Holding_N & $-0.552 * * *$ & $<0.01$ \\
\hline A_Class & $8.090 * * *$ & $<0.01$ \\
\hline Price $\geq \$ 1$ & $13.497 * * *$ & $<0.01$ \\
\hline$\$ 1 \leq$ Price $<\$ 5$ & $6.621 * * *$ & $<0.01$ \\
\hline$\$ 5 \leq$ Price $<\$ 10$ & $-1.98 * * *$ & $<0.01$ \\
\hline Price $\geq \$ 10$ & $3.118 * * *$ & $<0.01$ \\
\hline Price $\geq \$ 5$ & $6.038 * * *$ & $<0.01$ \\
\hline $\mathrm{N}$ & 1,512 & \\
\hline $\operatorname{Adj} R^{2}$ & 0.460 & \\
\hline
\end{tabular}

Table (6B): Ri = Information Ratio

\begin{tabular}{lcr}
\hline Independent Variable & Estimate & P-value \\
\hline Intercept & -0.0150 & -0.162 \\
Holding_N & $-0.0110^{* * * *}$ & $<0.01$ \\
A_Class & $0.1200^{* * *}$ & $<0.01$ \\
Price $>\$ 1$ & $0.1890^{* * *}$ & $<0.01$ \\
$\$ 1 \leq$ Price $<\$ 5$ & $0.0930^{* * *}$ & $<0.01$ \\
$\$ 5 \leq$ Price $<\$ 10$ & $-0.2500^{* * *}$ & $<0.01$ \\
Price $\geq \$ 10$ & $0.1502^{* * *}$ & $<0.01$ \\
Price $\geq \$ 5$ & $0.1030^{* * *}$ & $<0.01$ \\
$\mathrm{~N}$ & 1,512 & \\
Adj $\mathrm{R}^{2}$ & 0.5711 & \\
\hline$* * *$ denotes the statistical significance at the $1 \%$ level &
\end{tabular}

After the screening by the stepwise model, all the predictive variables are retained except the number of companies in the portfolios, suggesting that how many dogs are included in the portfolio is not important in predicting the risk adjusted returns. One potential explanation behind this phenomenon is that the Dogs of the Dow strategy identifies clusters of homogenous stocks with insignificant idiosyncratic volatility, especially stocks other than those between $\$ 1$ and $\$ 5$. The results raise two interesting points. First, the portfolio performance is more sensitive to the behavioral variables, such as stock price ranges and AB class. Switching among different price ranges and AB class dramatically impact both the compound return and risk adjusted return of the portfolio. Second, holding more stocks in the portfolio does not appear to improve either gross returns or risk-adjusted returns. This is in direct contradiction to theory on risk and diversification.

\section{CONCLUSION}

The distinct investment features and institutional setting of China's stock markets provide us a unique opportunity to examine the Dow Dogs strategy. In this study, we investigate the cross-sectional variation in the strength of the Dow Dogs effect over different price ranges in $\mathrm{A}$ and $\mathrm{B}$ shares in mainland China's stock markets. We find that the average turnover ratio for stocks priced between $\$ 1$ and $\$ 5$ and stocks in class $A$ is significantly greater than that of other subsamples, suggesting that these two categories of stocks attract most investors' attention and are associated with relatively naïve investors. Further analysis indicates that superior Dow Dogs performance is more pronounced for A shares than for B shares and for stocks priced between $\$ 1$ and $\$ 5$ than for stocks in other price ranges. This result is consistent with the explanation that irrational behavior on the investors proxied by share turnover ratio drives the market anomaly associated with the Dogs of the Dow strategy. Our study provides new empirical evidence which is consistent with behavioral finance literature and it sheds light on the long-debated Dogs of the Dow phenomena.

\section{REFERENCES}

Ainina, F., N. Mohan and D. James, 2010. Investment opportunities in Zombie Stocks. Financial Decisions.

Bailey, W., 1994. Risk and return on China's new stock markets: Some preliminary evidence. Pacific-Basin Finance J., 2: 243-260. DOI: 10.1016/0927538X(94)90019-1

Bao, B.H. and L. Chow, 1999. The usefulness of earnings and book value for equity valuation in emerging capital markets: Evidence from listed companies in the people's republic of china. J. Int. Financial Manage. Account., 10: 85-104. DOI: 10.1111/1467-646X.00045

Barber, B.M. and T. Odean, 1999. The courage of misguided convictions. Financial Anal. J.

Basu, S., 1977. Investment performance of common stocks in relation to their price-earnings ratios: A test of the efficient market hypothesis. J. Finance, 32: 663-682.

Black, F., 1993. Beta and return. J. Portfolio Manage., 20:8-18. DOI: 10.3905/jpm.1993.409462

Brown, P. and J. Mitchell, 2008. Culture and stock price clustering: Evidence from The Peoples' Republic of China. Pacific-Basin Finance J., 16: 95-120. DOI: 10.1016/j.pacfin.2007.04.005

Campbell, J.Y. and R.J. Shiller, 1988a. The dividendprice ratio and expectations of future dividends and discount factors. Rev. Financial Stud., 1: 195-228. DOI: $10.1093 / \mathrm{rfs} / 1.3 .195$

Campbell, J.Y. and R.J. Shiller, 1988b. Stock prices, earnings and expected dividends. J. Finance, 43: 661-676.

Cochrane, J.H., 2002. Stocks as money: Convenience yield and the tech-stock bubble. 1st Edn., National Bureau of Economic Research, Cambridge, pp: 28. 
Davis, J.L., E.F. Fama and K.R. French, 2000. Characteristics, Covariances and Average Returns: 1929 to 1997. J. Finance 55: 389-406. DOI: 10.1111/0022-1082.00209

De Bondt, F.M. Werner and R.H. Thaler. 1987. Further evidence on investor overreaction and stock market seasonality. J. Finance, 42: 557-581. DOI: $10.2307 / 2328371$

Domian, D.L., David A.L. and C.E. Mossman, 1998. The rise and fall of the "Dogs of the Dow". Financial Services Rev., 7: 145-159. DOI: 10.1016/S1057-0810(99)00007-4

Dorfman, J.R., 1988. Study of Industrial Averages Finds Stocks With High. Dividends Are Big Winners. Wall Street J.

Einhorn, H.J. and R.M. Hogarth, 1986. Decision making under ambiguity. J. Bus., 59: S225-S250.

Fama, E.F.1970. Efficient capital markets: A review of theory and empirical work. J. Finance, 25: 383417. DOI: $10.2307 / 2325486$.

Fama, E.F. 1998. Market efficiency, long-term returns, and behavioral finance. J. Financial Econ., 349: 283-306. DOI: 10.1016/S0304-405X(98)00026-9

Fama, E.F. and K.R. French, 1993. Common risk factors in the returns on stocks and bonds. J. Financial Econ., 33: 3-56. DOI: 10.1016/0304405X(93)90023-5

Fama, E.F. and K.R. French, 1995. Size and book-tomarket factors in earnings and returns. J. Finance 50: 131-155.

Fama, E.F. and K.R. French, 1996. Multifactor explanations of asset pricing anomalies. J. Finance, 51: $55-84$.

Fama, E.F. and K.R. French, 1998. Dividend yields and expected stock returns. J. Financial Econ., 22: 325. DOI: $10.1016 / 0304-405 X(88) 90020-7$

Hirschey, M., 2000. The "Dogs of the Dow" myth. Financial Rev., 35: 1-16. DOI: 10.1111/j.15406288.2000.tb01411.x
Hogarth, R.M. and M.W. Reder, 1986. Editors' comments: Perspectives from economics and psychology. J. Bus., 59: 185-207.

Kleidon, A.W., 1986. Anomalies in financial economics: Blueprint for change? J. Bus., 59: S469-S499.

Knowles, H.C and D. Petty, 1992. The dividend investor: A safe and sure way to beat the market with high-yield dividend stocks. 1st Edn., Irwin Professional Pub., Chicago, pp: 232.

Kothari, S. and J. Shanken, 1997. Book-to-market, dividend yield and expected market returns: A time-series analysis. J. Financial Econ., 44: 169203. DOI: 10.1016/S0304-405X(97)00002-0

La Porta, R., F. Lopez-de-Silanes, A. Shleifer and R. Vishny, 1998. Law and finance. J. Political Econ., 106: 1113-1155.

Lakonishok, J., A. Shleifer and R.W. Vishny, 1994. Contrarian investment, extrapolation and risk. J. Finance, 49: 1541-1578.

Baker, M. and J. Wurgler, 2000. The equity share in new issues and aggregate stock returns. J. Finance, 55: 2219-2257.

Mei, J., J.A. Scheinkman and W. Xiong, 2009. Speculative trading and stock prices: Evidence from Chinese A-B Share Premia. Annals Econ. Finance, 10-2: 225-255.

Merton, R.C., 1987. A simple model of capital market equilibrium with incomplete information. J. Finance, 42: 483-510.

O'Higgins, M and J. Downes, 1991. Beating the Dow. Harper Collins, New York. ISBN-10: 0066620473

Prather, L.J. and G.L. Webb, 2001. Window dressing, data mining, or data errors: a re-examination of the dogs of the dow theory. J. Applied Bus. Res.

Sun, Q and W.H.S. Tong, 2003. China share issue privatization: The extent of its success. J. Financial Econ., 70: 183-222. DOI: 10.1016/S0304405X(03)00145-4 